it is a notable addition to the literature of a subject which has recently attracted a good deal of attention, namely, the history of alchemy.

\section{Early Works on Medicine and Science}

WF have received from Messrs. Goldschmidt and Co., Ltd., 45 Old Bond Street, W.1, their Catalogue No. 53 listing rare early works on medicine and science. Pride of place is occupied by a good and large copy in vellum of the first edition of William Harvey's "De Motu Cordis" (1628), and also a copy of the rare third edition of the same work. A complete set of Conrad Gesner's "Natural History" (1551), three of Kepler's important works, a work by Joseph Black on alkalis (1770) and William Withering's "An Account of the Foxglove" are also to be noted. A number of less rare though none the less important books and tracts by Erasmus Darwin, Euler, Faraday, Fayrer, Fraunhofer, Stephen Hales, Mendeléeff, Pasteur, Lister, Fox Talbot and many others are also listed.

\section{Medical and Scientific Lending Library}

PART 2 of the new edition of the "Catalogue of Lewis's Medical and Scientific Lending Library", revised to the end of 1937 , has now been issued (London: H. K. Lewis and Co., Ltd., 136 Gower Street, W.C.1. 16s. net; to subscribers, 8s.). It contains the classified index of the subject-matter of the books, with the names of their authors, upon medical and scientific subjects contained in Lewis's Library. An extensive subject is subdivided to facilitate reference; for example, chemistry has eleven, and agriculture thirteen, sub-headings. The date of publication is given, and a note is frequently added to indicate the scope of the work. It will be appreciated what a large number of works is listed when it is mentioned that the text occupies 156 pages, each with three columns and each column containing authors' names of some 30-45 works. The catalogue should therefore prove a very useful general guide to medical and scientific books.

\section{Big Sunspots}

A BIG group of sunspots, originating about January 1 and growing rapidly, crossed the sun's central meridian on January 5 and reached the west limb on January 12. Between January 2 and 4, the area increased tenfold and measured 1,300 millionths of the sun's hemisphere on the latter date. Still expanding on January 5, the spots were clearly seen with the naked eye through the morning mist. In structure, the group was a typical stream with leader and follower spots and subsidiary spots in between. This group is the largest since last September, and indicates that, although the maximum of the 11year cycle is past, the sun is still generally active.

\section{Royal Institution Discourses}

The following Friday Evening Discourses have been arranged by the Royal Institution to be delivered before Easter. The discourses begin at 5 o'clock: January 19, Sir Leonard Woolley, "The
Latest Excavations at Atchana in North Syria"; January 26, Sir Noel Ashbridge, "Long Distance Broadcasting"; February 9, Prof. L. C. Martin, "Ultra-Violet and Electron Microscopy"; February 16, Sir William Bragg, "Physics in War-time"; March 1, Lord Eustace Percy, "Peace-making after War : Past History and Future Problems" ; March 8, Sir William Bragg, "Experiments from the Researches of Sir James Dewar"; March 15, Sir Frederick Keeble, "Agriculture and National Well-being".

\section{Announcements}

THE Harrison Lectureship Medal of the Pharmaceutical Society will be awarded to Mr. A. D. Powell at a meeting on January 9 at 7.30, when Mr. Powell will deliver the Harrison Memorial Lecture entitled "Drug Standards : their Development and Application".

THE next monthly meeting of the British Institute of Radiology will be held in the Reid-Knox Hall on January 19, at 2 p.m., when the following lectures will be delivered: Silvanus Thompson Memorial Lecture entitled "The Irradiation of Liquids", by Prof. F. L. Hopwood ; Mackenzie Davidson Memorial Lecture entitled "Maternal Mortality and Radiology", by Dr. L. A. Rowden.

The Friends of the National Libraries decided at their annual meeting to continue their activities during the War. Acquisitions during the year included a number of early and rare books on science presented to the Science Library at South Kensington, a volume of drawings by the architect, Edward Blore, of country houses and other buildings, given to the Royal Institute of British Architects, and the purchase of a collection of papers belonging to the publishing business of Robert Cadell, Stoneham and Houlston.

The Paris Academy of Medicine has awarded the Jansen Prize to Prof. A. Bessemans, pro-rector of the University of Ghent, for his work on spirochætes.

THe Albert Brachet Prize of 12,000 francs is awarded every three years for the best work on embryology published during this period in English, French, Dutch, German or Italian. Further information can be obtained from the Secrétarie perpétuel de l'Académie Royale des Sciences, des Lettres et des Beaux Arts de Belgique, Palais des Académies, Brussels.

The Emergency Executive Committee of the International Congress of Mathematicians has decided definitely to postpone until some more favourable date the Congress which was to have been held in Cambridge in September 1940.

A Eurasian Youth Movement has been launched in Singapore with a scheme to uphold and improve the social, moral, physical and intellectual welfare of the Eurasian youth when they leave school. 